M aria M arques, Jeferson Rosa and Kamilla Cruz

\title{
IN FLUENCE OF CHEMICAL TREATMENT ON SODIUM CLAY FOR OBTAINING POLYPROPYLENE NANOCOMPOSITES
}

\author{
Universidade Federal do Rio de Janeiro, Instituto de M acromoléculas Professora Eloisa M ano, \\ CP 68525, 21941-590, RJ , Brazil; fmarques@ima.ufrj.br
}

Received: August 30, 2011 / Revised: September 02, 2011 / Accepted: September 30, 2011

(C) Marques M., Rosa J., Cruz K., 2011

\begin{abstract}
Commercial clay was chemically treated with aluminum alkyl to prepare a Ziegler-Natta pro-catalyst containing $\mathrm{MgCl}_{2}$ and clay (as inert support) for the synthesis of polypropylene nanocomposites by in situ polymerization technique. The performance of this catalyst was compared with a reference one (catalyst prepared without clay), as well as with another one, composition of which presents the same clay content, without prior chemical treatment. Propylene polymerizations were performed varying the amount of external donor in the reaction medium in order to evaluate the response of catalysts toward increase in isospecificity. Properties of the polymeric materials obtained employing those catalysts were also compared. The results showed a marked reduction in activity of both bisupported catalysts in comparison with that of the reference system, and a slight reduction in polypropylene melting temperature. The melt flow index of polymers obtained with the treated clay was notably higher than those synthesized with the untreated clay. Therefore, the treated clay caused the production of PP with a lower molar mass. On the other hand, the clays showed an increase of the d-spacing and irregular stacking of the lamellas in the bisupported catalyst and also in the produced PP/clay nanocomposites, especially when using the chemically treated clay.
\end{abstract}

Keywords: nanocomposite; polypropylene; clay treatment; in situ polymerization; bissuported catalyst.

\section{Introduction}

There is a growing interest in the preparation of polymer-layered silicate nanocomposites, especially based on polyolefins, using in situ polymerization method. This technique has an undeniable advantage, since it allows circumventing problems related to incompatibility between polyolefin and hydrophilic nanofillers. To improve the affinity of clay and polyolefins, long chain alkyl-ammonium surfactants have been used to modify smectite type clays such as montmorillonite (MMT). It was found that the thermal degradation of such alkylammonium interlayer cation at high processing temperatures not only accelerates the aging and decomposition of polyolefins but also leads to the restacking of the silicate layers. Therefore, the in situ technique also prevents the degradation of the polymer matrix that can occur when using the melt intercalation method, which requires high shear forces in the extrusion [1].

Polyolefin is one of the most interesting polymer families to be considered for benefiting with the production of nanocomposites because of the possibility of vastly broadening its applications [2]. Among the polyolefins, polypropylene (PP) is a plastic with high performance and cost-benefit, and their tenacity, Young's modulus and barrier properties are expected to be improved when loaded with a nanofiller. Therefore, its application could be extended in the automotive and packaging areas, as a substitute for engineering plastics with high performance [3-7].

In fact, in situ polymerization has been recently considered as the most suitable method for clay exfoliation during the synthesis of polyolefin nanocomposites [8-10]. In this approach, the active sites of the catalyst for olefin polymerization must be introduced in the clay galleries and by polymerization of the monomer between the clay layers, the silicate will exfoliate and disperse uniformly in the polymer matrix.

However, the production of polypropylene/clay nanocomposites (PPCNC) via intercalative polymerization has been found only in few articles, mostly employing single-site catalysts [11-14]. Studies using Ziegler-Natta heterogeneous catalysts with clay based on $\mathrm{MgCl}_{2} / \mathrm{TiCl}_{4}$ are rather limited. Aihua He and coworkers [6] reported about the synthesis of highly exfoliated polypropylene/clay nanocomposites with improvements in both tensile strength and toughness by $\mathrm{TiCl}_{4} / \mathrm{MgCl}_{2} / \mathrm{imi}$ dazolium-modified montmorillonite catalysts. Through 
this approach, they affirmed that in situ propylene polymerization has actually taken place between the silicate layers and led not only to PP with a high isotacticity and molecular weight, but also to a highly exfoliated structure even at high clay content levels (as high as $19 \mathrm{wt} \%$ ).

Ramazani et al. [15] reported about the use of $\mathrm{ZN}$ catalyst based on bisupported $\mathrm{MgCl}_{2} / \mathrm{MMT}$ catalyst to prepare $\mathrm{PP} /$ clay nanocomposites. Montmorillonite was used as an inert support and reinforcement agent. The authors employed sodium-MMT and $\mathrm{Mg}(\mathrm{OEt})_{2}$ precursor with different weight ratios for the preparation of the catalysts. Obtained results showed that the silica layers of MMT in these PPNCs were intercalated, partially exfoliated, and uniformly dispersed in the polypropylene matrix. Moreover, DSC analysis showed increase in melting and crystallization temperature, and reduction in crystallinity of prepared nanocomposites.

Non-modified smectite type clay (bentonite) was also used to prepare bi-supported Ziegler-Natta catalyst of $\mathrm{TiCl}_{4} / \mathrm{Mg}(\mathrm{OEt})_{2} /$ clay [16]. Exfoliated PPNCs were obtained by in situ intercalative polymerization of propylene. X-ray diffraction (XRD) patterns and transmission electron microscopy (TEM) micrograph were used to assess the clay morphology and dispersion of clay. The thermomechanical properties of prepared nanocomposites were considerably improved by introducing small amount of clay, which indicated that the clay must be significantly intercalated or exfoliated in the prepared nanocomposites.

In the present study, commercial clay was chemically treated by aluminum alkyl and mixed with $\mathrm{MgCl}_{2}$ to prepare Ziegler-Natta (ZN) catalyst containing internal electron donor (ID). The performance of this catalyst was compared with a reference one without clay addition, and also with another catalyst with unmodified clay, prepared likewise. The influence of the amount of $\mathrm{ED}$ in the polymerization medium was also evaluated.

\section{Experimental}

\subsection{M aterials}

High purity $\mathrm{N}_{2}$ (W. Martins, $99.9 \%$ purity) and propylene (Rio Polímeros) were further purified prior to use after sequentially passing them through the columns containing 3A molecular sieves and copper catalyst columns. Hexane (Petroflex), used as a solvent for polymerization and catalyst preparation, were treated with molecular sieves and bubbled with nitrogen before use. Titanium tetrachloride (Aldrich) was distilled under nitrogen. The employed clay was a commercial sodium clay Argel 55 (Bentonit União Nordeste Ind. e Com.
Ltda). All the other materials were used as received: $\mathrm{MgCl}_{2}$ (Toho, Japan), triethylaluminium (Aldrich), butyl phthalate (Aldrich, $\geq 95 \%$ purity), dimethoxydiphenylsilane (ToKyo Kasei Kogyo Co.), hydrochloric acid (Vetec Química Fina, PA), hydrogen peroxide (Vetec Química), boric acid (Montedison Farmacêutica), and phosphoric acid (Vetec Química).

\subsection{Clay Treatment}

Commercial sodium clay was introduced in a vessel, under nitrogen atmosphere and triethylaluminium $10 \%$ solution, used as a treatment agent, was added dropwise with gentle agitation. After two hours, this clay was washed with hexane, followed by drying at $393 \mathrm{~K}$.

\subsection{Catalyst Preparation}

The air-sensitive substances were manipulated under an inert atmosphere of dry nitrogen. In the preparation of the first catalyst (Catalyst 1, without clay), anhydrous magnesium chloride and butyl phthalate (internal electron donor) were placed in a ceramic grinding jar and ball milled at $30 \mathrm{rpm}$ for $30 \mathrm{~h}$, using 30 balls with $10 \mathrm{~mm}$ diameter. The ground product was transferred to a Schlenk flask and heated with $\mathrm{TiCl}_{4}$ $(30 \mathrm{ml})$ for $2 \mathrm{~h}$ at $383 \mathrm{~K}$, followed by washing with hexane. The type and concentration of internal electron donor were varied. Also using the milled mixture of $\mathrm{MgCl}_{2}$ and butyl phthalate, two other catalysts were prepared containing 20 wt $\%$ in clay: Catalyst 2 using the untreated commercial clay and, Catalyst 3 using the treated clay. The titanium content of the catalysts was measured using the conventional calorimetry method, using a wavelength of $405 \mathrm{~nm}$ (Turner SP-870 UV-Vis spectrophotometer).

\subsection{Polymerization}

Propylene polymerization was carried out in a Büchi reactor (Brooks-5850D) equipped with a mechanical stirrer, connected to a thermostatic system. Hexane $(100 \mathrm{ml})$ was used as a diluent. The amount of triethylaluminium used in all the polymerizations was $12.5 \mathrm{M}$ in relation to $1 \mathrm{~g}$ of the supported catalyst. The concentration of external electron donor (dimethoxydiphenylsilane) in the system was varied. Reactor temperature and pressure were maintained constant at $343 \mathrm{~K}$ and $200 \mathrm{kPa}$ for $1 \mathrm{~h}$. The polymerizations were quenched with $5 \% \mathrm{HCl}$ in ethanol solution. The polymers obtained were filtered, washed and dried under vacuum at $323 \mathrm{~K}$ to constant weight. Clay content was calculated considering the polymerization yield and the amount of clay in the polymerization introduced by the bisupported catalyst. 


\subsection{Polymer Characterization}

Differential scanning calorimetry (TA Instruments, DSC model Q 1000) was conducted under nitrogen atmosphere to determine the melting and crystallization temperatures $\left(T_{m}\right.$ and $\left.T_{c}\right)$ of the synthesized polymers, and their crystalline degree $\left(X_{c}\right)$ by measuring the melting enthalpy of the material at the second heating. Correction was applied considering the weight fraction of the filler in the composite. Thus, about $10 \mathrm{mg}$ samples were heated from room temperature to $453 \mathrm{~K}$ using a heating rate of $10 \% \mathrm{~min}$.

The equipment Dynisco Polymer Test LMI 4000, was used for measuring the melt flow index (MFI) values of the produced PP. The analysis was conducted using the method based on ASTM D-1238 at $503 \mathrm{~K}$ for a melting time of $240 \mathrm{sec}$.

In order to observe the variation of the clay interlayer space in the prepared catalysts, as well as in the materials obtained in the polymerizations, wide angle $\mathrm{X}$-ray diffractometry (XRD) was performed on samples with a Rigaku Miniflex equipment at a potential difference of $30 \mathrm{kV}$ and electric current of $15 \mathrm{~mA}$. The scan was performed in the range of $2 \theta$ from $2^{\circ}$ to $30^{\circ}$, with goniometer speed $0.05 \% \mathrm{~min}$. The radiation used was that of $\mathrm{Cu}_{\mathrm{K} \alpha}$ with $\lambda=1.5418 \AA$.

The thermal degradation behavior was studied using a thermogravimetric analyzer (TGA) from TA Instruments (Q-500) at a heating rate of $10 \%$ min to $973 \mathrm{~K}$ under nitrogen flow. The isotactic index (I.I.) of the produced polypropylene was determined from the insolub- le fraction in boiling heptane. The extraction was performed for $8 \mathrm{~h}$ using a Soxhlet extractor.

\section{Results and Discussion}

Table 1 shows the results obtained by polymerization carried out with the prepared catalysts, as well as the characterization of catalysts in terms of titanium content. Polypropylenes were synthesized with those catalysts at increasing amounts of external donor (ED) in the reaction medium in order to observe if the catalysts respond to ED aiming the increase of polymer isotacticity.

Catalyst 2 (with unmodified clay) presented the increased amount of titanium in comparison with that of the reference catalyst, while catalyst 3 (with aluminum alkyl-modified clay) has decreased titanium content. The increased value was probably due to the fixation of high amounts of $\mathrm{Ti}$ in the hydroxyl groups of the untreated clay, although it is well known that the obtained Si-O$\mathrm{TiCl}_{3}$ sites in the clay platelets surface will not act as an active polymerization catalyst after introduction of TEA in the reaction medium as a cocatalyst [17]. Actually, the catalyst activity was low despite the higher Ti content of catalyst 2 . On the other hand, the prior aluminum alkyl treatment performed on the clay has decreased the $\mathrm{Ti}$ content in the catalyst, meaning that this clay was inert for the fixation of $\mathrm{TiCl}_{4}$. In fact, we have performed an impregnation of this clay directly with $\mathrm{TiCl}_{4}$ and the amount of Ti fixed in this material was less than $0.5 \mathrm{wt} \%$. Therefore, in the bisupported Ziegler-Natta catalyst $\mathrm{MgCl}_{2}$ is the actual active support for $\mathrm{TiCl}_{4}$.

Table 1

Results of polymerization yield and the characterization analysis of catalysts and the obtained polypropylenes

\begin{tabular}{|c|c|c|c|c|c|c|c|}
\hline & Sample & $\begin{array}{c}\text { Polymer } \\
\text { yield, g/g } \\
\text { of catalyst }\end{array}$ & $T_{m}, \mathrm{~K}$ & $T_{c}, \mathrm{~K}$ & $X_{c}^{*}, \%$ & Clay, $\%$ & I.I. $*, \%$ \\
\hline \multirow{4}{*}{$\begin{array}{c}\text { Catalyst } 1 \\
2.4 \mathrm{wt} \% \text { of } \\
\mathrm{Ti}\end{array}$} & PP1-A & 57 & 429 & 395 & 43 & - & 56 \\
\hline & PP1-B & 68 & 436 & 400 & 48 & - & 94 \\
\hline & PP1-C & 141 & 436 & 397 & 57 & - & 98 \\
\hline & PP1-D & 107 & 435 & 398 & 41 & - & 93 \\
\hline \multirow{4}{*}{$\begin{array}{c}\text { Catalyst } 2 \\
5.5 \mathrm{wt} \% \text { of } \\
\mathrm{Ti}\end{array}$} & PP2-A & 13 & 427 & 392 & 35 & 6 & 56 \\
\hline & PP2-B & 17 & 432 & 398 & 47 & 5 & 85 \\
\hline & PP2-C & 18 & 431 & 394 & 44 & 4 & 82 \\
\hline & PP2-D & 14 & 433 & 399 & 55 & 6 & 87 \\
\hline \multirow{4}{*}{$\begin{array}{c}\text { Catalyst } 3 \\
1.4 \mathrm{wt} \% \text { of } \\
\mathrm{Ti}\end{array}$} & PP3-A & 17 & 431 & 395 & 29 & 5 & 51 \\
\hline & PP3-B & 11 & 430 & 396 & 46 & 7 & 81 \\
\hline & PP3-C & 12 & 431 & 398 & 52 & 7 & 78 \\
\hline & PP3-D & 13 & 431 & 396 & 51 & 6 & 86 \\
\hline
\end{tabular}


When catalyst 1 was employed, an enhance in activity with increasing amounts of external donor was observed, reaching a maximum when the concentration of ED was $0.25 \mathrm{~mol} / \mathrm{l}$. Similar behavior occurred in relation to the values of polymer $T_{m}$ and $X_{c}$, i.e., higher values were obtained at this ED concentration. These behaviors are due to the fact that the external electron donor provides the increase of the catalyst stereospecificity, by selective poisoning of aspecific centers, with a consequent increase in the crystalline arrangement of the isotactic PP chains. Excess of ED has decreased polymer yield because of the competition of ED and monomer to the active sites.

Table 1 also shows that the addition of commercial clay leads to a great decrease in activity for catalysts 2 and 3 when compared with catalyst 1 . This may be due to the confinement of the active sites in the interlayer of the clay at the beginning of polymerization. The melting temperatures of the PPs produced in this series were generally slightly lower than those of the series produced without clay. However, with the addition of higher concentration of external donor $(0.50 \mathrm{~mol} / \mathrm{l}), T_{m}$ and $X_{c}$ of the PPs products increased sharply. Without ED in the reaction medium the synthesized PP presented much lower thermal properties, i.e., lower index of isotacticity. Clay content incorporated in the produced polymers was similar in all reactions with the use of catalysts 2 and 3.

Polymer yields achieved in the reactions with catalyst 3 , which employed pre-treated clay, seem to be slightly lower than those of catalyst 2 . However, in the absence of external donor, both the catalyst activity and the $T_{m}$ of PP were also rather higher.

Fig. 1 shows the influence of chemical treatment of clay in the polymer melt flow index (MFI), where it can be seen that the PPs obtained with catalyst 2 (prepared with untreated clay) have lower MFI than those synthesized from catalyst 3 (with treated clay).

It can be also noted that at each increase in the amount of external donor in the polymerization medium, the PPs presented lower MFI, although for the polypropylenes of series 2 this reduction was more discreet than for those synthesized with catalyst 3 .
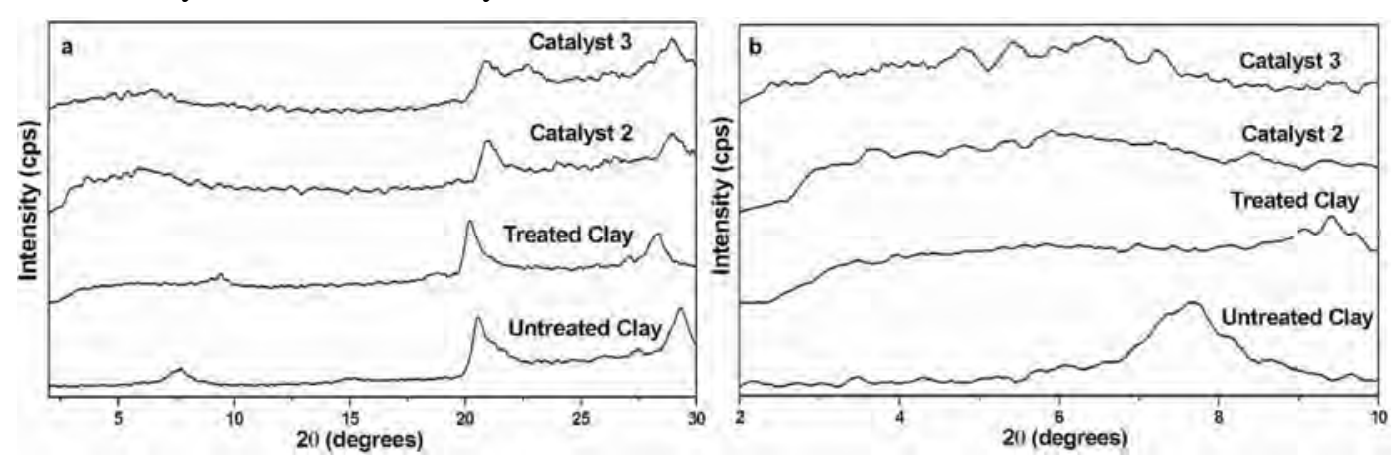

Fig. 2. Results of XRD of commercial clay before and after chemical treatment and catalysts prepared with these clays: $0-30^{\circ}$ (a) and $0-10^{\circ}$ (b)
Since the MFI is a parameter inversely proportional to the polymer molecular weight, therefore the polymers obtained with higher external donor content have higher molecular weight and the PPs produced with catalyst 2 (untreated clay) have also higher molecular weight than those obtained with the catalyst 3, as shown in Fig. 1. Possibly, the chemical agent used in the clay treatment and employed in the preparation of catalyst 3, have promoted more chain transfer reactions, thus reducing the molecular weight of PPs synthesized in this series.

Fig. 2 shows the results of $\mathrm{X}$-ray diffraction analysis (XRD) for the employed commercial clay before and after chemical treatment, as well as the diffractograms of their respective catalysts. In Fig. 2a, the characteristic diffraction peak of the commercial clay is located at $2 \theta$ equal to $7.7^{\circ}$, and after chemical treatment, it has suffered a sharp enlargement. This diffraction peak corresponds to the clay interlamellar spacing, and in Fig. $2 b$ it can be clearly noticed that the chemical treatment has enlarged its basal spacing. This means that the clay lamellas have irregular stacking, with different interlamellar spaces, favoring the inclusion of catalyst components in these spaces. It can be also observed that the main peak was shifted to higher angles, meaning that part of the $\mathrm{d}$-spacing has become smaller than that of the original clay, probably due to the dehydration of the clay.

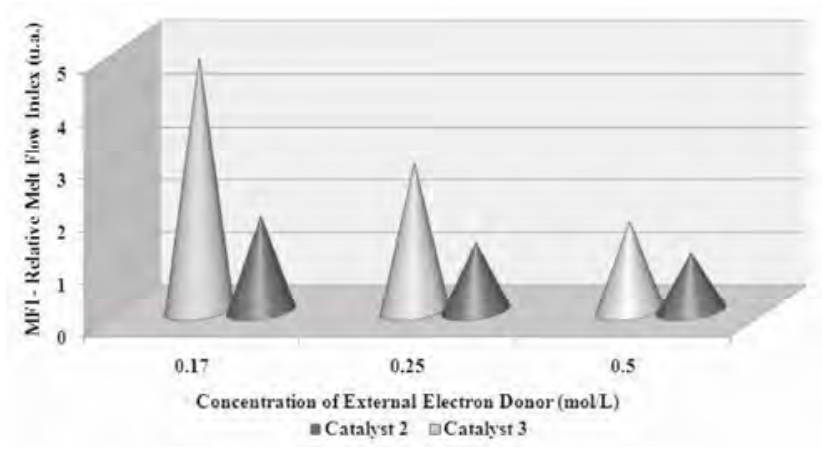

Fig. 1. Influence of the clay treatment and the concentration of electron donor on MFI of the synthesized polypropylenes 

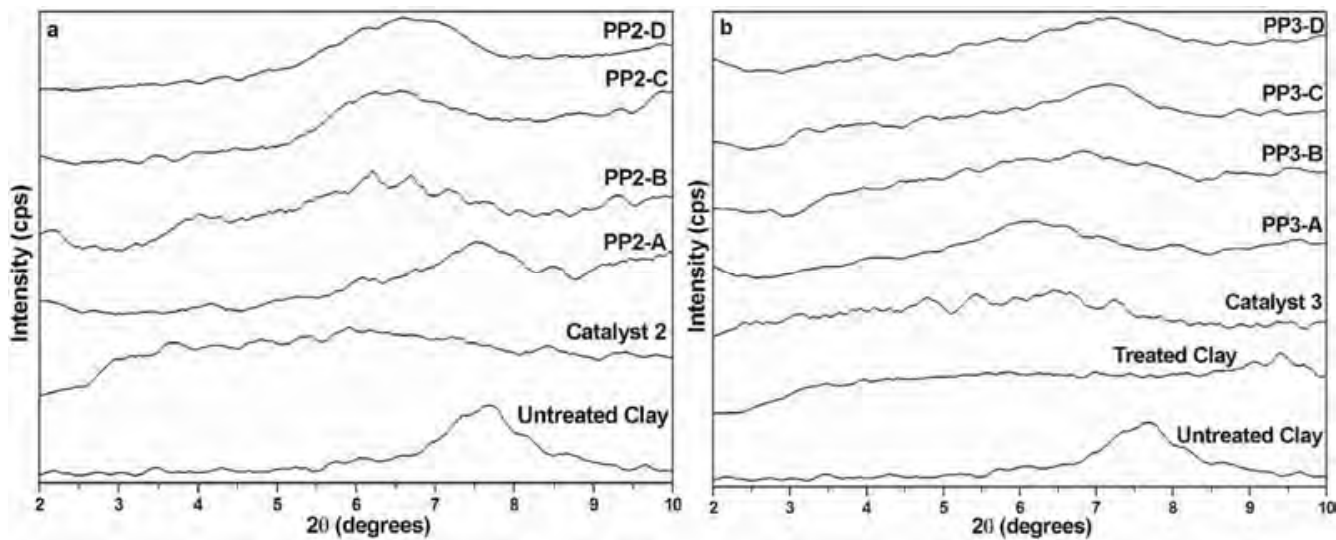

Fig. 3. Results of XRD of PPs obtained from their respective catalysts, commercial clay: untreated (a) and after chemical treatment (b)
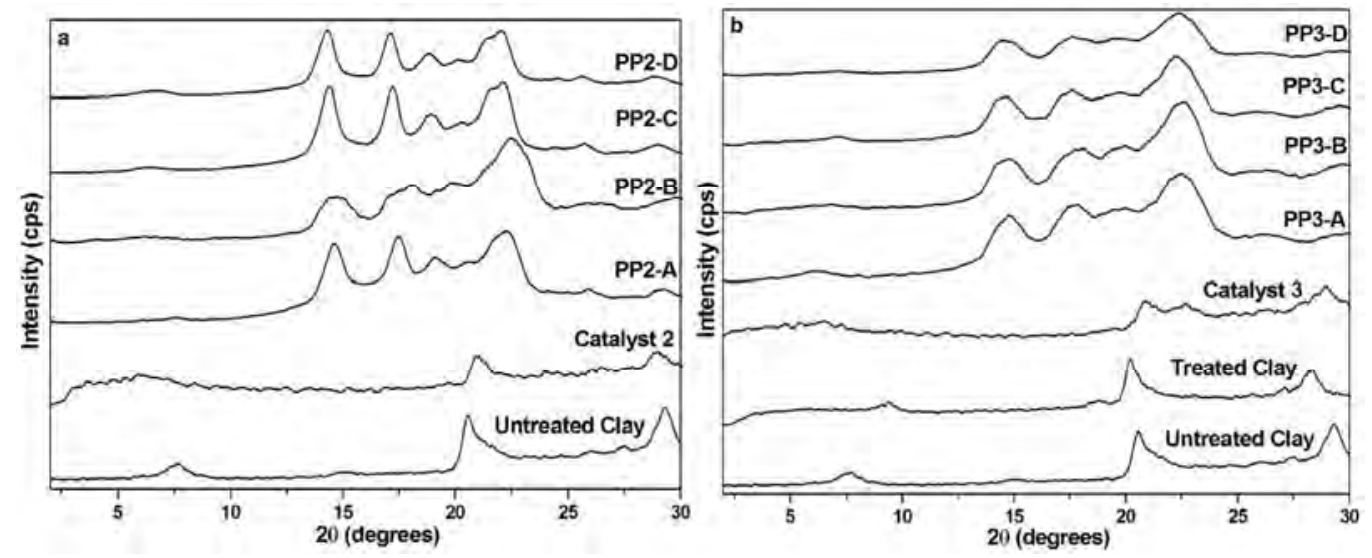

Fig. 4. XRD diffractograms of the PP/clay: untreated (a) and after chemical treatment (b)

Table 2

Thermogravimetric analysis of obtained materials

\begin{tabular}{|c|c|c|c|c|c|}
\hline Catalyst & Sample & $T_{\text {onset }}, \mathrm{K}$ & $T_{\max }, \mathrm{K}$ & $T_{\max }-T_{\text {onset }}, \mathrm{K}$ & Residue at 973 K, \% \\
\hline \multirow{4}{*}{ Catalyst 1 } & PP1-A & 629 & 665 & 36 & 0.7 \\
\cline { 2 - 6 } & PP1-B & 622 & 665 & 43 & 0.6 \\
\cline { 2 - 6 } & PP1-C & 617 & 663 & 46 & 0.0 \\
\cline { 2 - 6 } & PP1-D & 634 & 675 & 41 & 0.4 \\
\hline \multirow{4}{*}{ Catalyst 2 } & PP2-A & 699 & 716 & 17 & 5.1 \\
\cline { 2 - 6 } & PP2-B & 650 & 711 & 61 & 6.7 \\
\cline { 2 - 6 } & PP2-C & 611 & 669 & 58 & 4.7 \\
\cline { 2 - 6 } & PP2-D & 604 & 664 & 60 & 5.7 \\
\hline \multirow{3}{*}{ Catalyst 3 } & PP3-A & 609 & 672 & 63 & 6.9 \\
\cline { 2 - 6 } & PP3-B & 631 & 674 & 22 & 6.2 \\
\cline { 2 - 6 } & PP3-C & 705 & 727 & 54 & 9.7 \\
\cline { 2 - 6 } & PP3-D & 578 & 632 & & \\
\hline
\end{tabular}

Therefore, the diffractions showed in both bisupported catalysts (catalysts 2 and 3) were extremely enlarged in this angular region, with maximum intensity angles much lower than that of the original clay. This indicates that the catalyst components have been inserted in the clay interlamellar spaces.
During the polymerization with catalyst 2 , the chains of polypropylene were synthesized in the clay interlayer space. This can be noticed with the shift of the peak from the original clay basal angle to lower angles (Fig. 3a). Therefore, except for PP obtained without the addition of $\mathrm{ED}$, i.e., with low isotacticity, the material 
formed is possibly an intercalated polypropylene nanocomposite. On the other hand, for PP3, obtained with the catalyst containing the treated clay, the increase of ED concentration has broadened the peak corresponding to the galleries distance of the clay, which is an indicative of a broad distribution of interlayer distances.

Regarding to the crystalline form of PPs synthesized with both prepared catalysts (Fig. 4), it is possible to observe the mainly monoclinic $\alpha$-phase diffractions at $2 \theta=13.9^{\circ} ; 16.8^{\circ} ; 18.4^{\circ}$ and $21.1^{\circ}+21.8^{\circ}$, corresponding respectively to the planes (110), (040), (130) and $(041)+(111)$. It seems that some imperfect $\gamma$ PP crystals (Fig. $4 a$ ) at $2 \theta=15.1^{\circ}$ (plane 113) and 20.3 (117) coexists with the majority $\alpha$-form PP [18] when prepared with the untreated clay catalyst.

Table 2 presents the results of thermogravimetric analyses of the polypropylene/clay nanocomposites.

The residues after heating to $973 \mathrm{~K}$ correspond approximately to the amount of clay in the composite, as calculated in Table 1. Moreover, an increase in the degradation temperature can be noticed for the PP/clay obtained with both bisupported catalysts in comparison with the PPs produced with the reference catalyst. A reduction of the difference between $T_{\text {max }}-T_{\text {onset }}$ was observed, indicating a sharp degradation profile, which is typical for nanocomposites.

\section{Conclusions}

In this work, polypropylene/clay nanocomposites have been synthesized by in situ polymerization using Ziegler-Natta catalysts based on $\mathrm{MgCl}_{2} /$ clay-TiCl$_{4}$ employing sodium clay and alkyl-aluminum pretreated clay. The effect of external donor concentration in the polymerization medium was evaluated using each catalyst.

It can be inferred, according to the MFI results, that the polymers synthesized with the catalyst 3 (containing treated clay) have lower molecular weight than those produced from catalyst 2 (untreated clay).

$\mathrm{X}$-ray diffractometry revealed that it was possible to insert the catalyst components in the clay lamellae, especially with the chemically treated clay, since the diffraction peak characteristic of the clay have shifted to smaller angles and became broader. Some $\gamma$-PP crystals were also observed in the materials produced with the catalyst containing nontreated clay. Moreover, an increase in the thermal stability of polypropylene/clay was noticed when compared with the PPs obtained with the reference catalyst.

In the presence of $\mathrm{ED}$ in the reaction medium the isospecificity of the catalysts with clay has increased in a similar behavior as the catalyst without clay, although I.I. is lower in these former catalysts.

\section{Acknowledgments}

The authors thank CAPES, CNPq and Petrobras.

\section{References}

[1] Ivanyuk A., Gerasin V., Rebrov A. et al.: J. Eng. Phys. Thermophys., 2005, 78, 926.

[2] Huang Y., Yang K. and Dong J.: Polymer, 2007, 48, 4005.

[3] Zhang Y.-Q., Lee J.-H., Rhee J. and Rhee K.: Compos. Sci. Technol., 2004, 64, 1383.

[4] He A., Hu H., Huang Y. et al.: Macromol. Rapid Commun., 2004, 25, 2008.

[5] He A., Hu H., Wang L. et al.: Polymer, 2006, 47, 1767.

[6] Du K., He A., Liu X. and Han C.C.: Macromol. Rapid Commun., 2007, 28, 2294.

[7] Yang K., Huang Y. and Dong J.-Y.: Polymer, 2007, 48, 6254.

[8] Kaminsky W.: Macromol. Chem. \& Phys., 2008, 209, 459.

[9] Qin Y. and Dong J.: Chinese Sci. Bull., 2009, 54, 38.

[10] Marques M. and Tiosso R.: Chem. \& Chem. Technol., 2010, 4, 139.

[11] Zhong C. and Mao B.: J. Appl. Polym. Sci., 2009, 114, 2474.

[12] Hwu J. and Huang G.: J. Appl. Polym. Sci., 2005, 95, 1228.

[13] Marques M. and Oliveira M.: Polym. Bull., 2010, 64, 221.

[14] Scott S., Peoples B., Yung C. et al.: Chem. Commun., 2008, 35, 4186.

[15] Ramazani A., Tavakolzadeh F. and Baniasadi H.: J. Appl. Polym. Sci., 2010, 115, 308.

[16] Baniasadi H., Ramazani S. and Nikkhah S.: Mater. Desig., 2010, 31, 76.

[17] Soga K., Sano T. and Ikeda S.: Polym. Bull., 1980, $2,817$.

[18] Zong C. and Mao B.: J. Appl. Polym. Sci., 2009, 114, 2474.

\section{ВПЛИВ ХІМІЧНОГО ОБРОБЛЕННЯ НАТРІЄВОЇ ГЛИНИ НА ОТРИМАННЯ ПОЛІПРОПІЛЕНОВИХ НАНОКОМПОЗИТІВ}

Анотація. Промислову глину було хімічно оброблено алкілалюмінієм для приготування про-каталізатора ЦиглераНатта, щзо містить $\mathrm{MgCl}_{2}$ i глину (як інертний носій), для синтезу поліпропіленових нанокомпозитів внаслідок полімеризачіi in situ. Проведено порівняння ефективності синтезованого каталізатора з еталонним (каталізатора без глини), а також з каталізатором, який містить глину, але не пройтов хімічного оброблення. Для оиінювання реакиії каталізаторів на збільшення ізоспецифіки проведено полімеризачію пропілену, змінюючи кількість зовнішніх донорів в реакиійному середовищі. Зроблено порівняння властивостей полімерних матеріалів, отриманих при застосуванні иих каталізаторів. Встановлено помітне зниження активності обох каталізаторів на бі-носії порівнянні з еталонною системою, $i$ невелике зниження температури плавлення поліпропілену (ПП). Показано, щзо показник плинності розплаву полімерів, отриманих при обробленні глини, помітно вищий у порівнянні з полімерами, синтезованими за допомогою необробленої глини. Показано, що оброблення глини призводить до одержання ПП з нижчою молекулярною масою. Показано збільшення d-відстані і нерегулярного укладання пластинок в каталізаторі на бі-носії, а також в одержаних нанокомпозитах ПП/глина, особливо при використанні хімічно обробленої глини.

Ключові слова: нанокомпозит, поліпропілен, оброблення глини, полімеризація іп situ, каталізатор на бі-носї. 